\title{
EVALUSI PEMBERIAN BUAH PISANG AMBON (MUSA PARADISIACA VAR. SAPIENTUM LINN) TERHADAP PENURUNAN TEKANAN DARAH PENDERITA HIPERTENSI DI WILAYAH KERJA PUSKESMAS TAMBAH SUBUR KEC. WAY BUNGUR LAMPUNG TIMUR
}

\author{
Ari Khusuma ${ }^{1}$, Arini Pradita Roselyn ${ }^{2}$, Annisa Agata ${ }^{3}$ \\ ${ }^{1}$ Jurusan Analis Kesehatan, Poltekkes Kemenkes Mataram, Indonesia \\ ${ }^{2}$ Jurusan Biologi, Universitas Lampung, Indonesia \\ ${ }^{3}$ Jurusan Ilmu Keperawatan, Universitas Mitra Indonesia, Lampung, Indonesia
}

\section{Article Info \\ Article history: \\ Received July $2^{\text {th }}, 2018$ \\ Revised August $10^{\text {th }}, 2018$ \\ Accepted Sept $12^{\text {th }}, 2018$}

Keyword:

Anemia

Hemoglobin Level

Date Fruit

\begin{abstract}
Hypertension or high blood pressure is a condition where a person experiences an increase in blood pressure above normal. The incidence of hypertension in the world reaches around 970 million sufferers, 330 million in developed countries and 640 in developing countries. Pre-survey data shows the incidence of hypertension in East Lampung in 2017 reached 2,972 cases and in the Subur Addition Health Center reached 375 cases. One of the efforts to reduce blood pressure of hypertensive patients is by consuming fruits that are high in potassium such as Ambon bananas. The purpose of this study is to determine the effect of Ambon banana (Musa Paradisiaca var. Sapientum Linn) on blood pressure in hypertensive patients in the Puskesmas Add Subur Work Area, Way Bungur District, East Lampung .The design of this study used pre experimental design, the population in this study were 374 people with hypertension. The sample used was 25 people with the sampling technique using purposive sampling. The analysis in this study uses paired t-test. Statistical test results showed that the average blood pressure of hypertensive patients before (pre-test) administration of ambon bananas was $149.00 / 94.52 \mathrm{mmHg}$ with a standard deviation of 5,132/2,468 and after (post-test) administration of ambon bananas 140, 04 / $89.88 \mathrm{mmHg}$ with a standard deviation of 5,697 / 5,199 . The results of the analysis with paired sample t-test obtained p-value 0,000 $<\alpha 0,05$, it can be concluded that there was an effect of ambon bananas on the reduction in blood pressure of hypertensive patients, where the average blood pressure of hypertensive patients after being treated was significantly lower than before being treated. It is recommended for patients with hypertension should be able to maintain high diet intake of fruit, especially those that contain high levels of water and potassium.
\end{abstract}

\section{ABSTRAK}

Hipertensi atau penyakit darah tinggi adalah suatu keadaan dimana seseorang mengalami peningkatan tekanan darah di atas normal. Angka kejadian hipertensi di dunia mencapai sekitar 970 juta penderita, 330 juta terdapat di negara maju dan 640 terdapat di negara berkembang. Data pra survei menunjukkan angka kejadian hipertensi di Lampung Timur tahun 2017 mencapai 2.972 kasus dan di Puskesmas Tambah Subur mencapai 375 kasus. Salah satu upaya untuk menurunkan tekanan darah penderita hipertensi diantaranya 
dengan mengkonsumsi buah yang tinggi kalium seperti buah pisang ambon. Desain penelitian ini menggunakan pre-experimental design, populasi dalam penelitian ini sebanyak 374 orang penderita hipertensi. Sampel yang digunakan sebanyak 25 orang dengan teknik pengambilan sampel menggunakan purposive sampling. Analisis dalam penelitian ini menggunakan uji paired t-test. Hasil uji statistik menunjukkan bahwa rata-rata tekanan darah penderita hipertensi sebelum (pre-test) pemberian buah pisang ambon adalah 149,00/94,52 $\mathrm{mmHg}$ dengan standar deviasi 5,132/2,468 dan setelah (post-test) pemberian buah pisang ambon 140,04/89,88 mmHg dengan standar deviasi 5,697/5,199. Hasil analisis dengan paired sample t-test didapatkan p-value $0,000 \& \mathrm{lt} ; \square 0,05$ maka dapat disimpulkan bahwa ada pengaruh buah pisang ambon terhadap penurunan tekanan darah penderita hipertensi, dimana rata-rata tekanan darah penderita hipertensisetelah diberi perlakuan lebih rendah secara bermakna dibandingkan sebelum diberi perlakuan. Disarankan bagi penderita hiperhenti hendaknya dapat mempertahankan asupan diit tinggi buah terutama yang banyak mengandung tinggi air dan kalium.

Kata Kunci : Buah pisang ambon (Musa Paradisiaca var. Sapientum Linn); tekanan darah; hipertensi

Copyright $\odot$ Jurnal Analis Medika Bio Sains

\section{Pendahuluan}

Hipertensi sering menyebabkan perubahan pada pembuluh darah yang mengakibatkan makin tingginya tekanan darah. Tekanan darah sendiri merupakan salah satu parameter hemodinamik yang sederhana dan mudah dilakukan pengukurannya. Hemodinamik merupakan suatu keadaan dimana tekanan dan aliran darah dapat mempertahankan perfusi atau pertukaran zat di jaringan tubuh (Muttaqin, 2014). Hipertensi adalah salah satu isu kesehatan masyarakat yang sangat penting mengingat penyakit ini merupakan faktor risiko utama pada penyakit jantung koroner, gagal jantung dan stroke (Lemone, et al, 2016).

Menurut World Health Organization (WHO), saat ini penderita hipertensi di dunia mencapai sekitar 970 juta penderita, sekitar 330 juta terdapat di negara maju dan 640 terdapat di negara berkembang. Di Amerika Serikat hipertensi merupakan diagnosa primer yang umum karena menyerang hampir 50 juta penduduk dimana sekitar $69 \%$ orang dewasa yang telah melewati 18 tahun sadar akan hipertensi yang mereka derita dan $58 \%$ dari mereka dirawat, tetapi hanya $31 \%$ yang terkontrol. Prevalensi hipertensi di benua Amerika lebih rendah dibandingkan di benua Eropa, dimana prevalensi hipertensi di Amerika Serikat 20,3\% dan Kanada 21,4\% sedangkan di beberapa Negara Eropa seperti Swedia 38,4\%, Italia 37,7\%, Inggris 29,6\%, Spanyol 40\% dan Jerman 55,3\% (WHO, 2017).

Prevalensi hipertensi secara nasional berdasarkan wawancara terjadi peningkatan yaitu dari 7,6 persen pada tahun 2007 menjadi 9,5 persen pada tahun 2013. Sementara prevalensi berdasarkan hasil pengukuran terjadi penurunan yaitu dari $31,7 \%$ menurun menjadi $25,8 \%$. Provinsi dengan prevalensi hipertensi pada umur $\geq 18$ tahun berdasarkan pengukuran yang tertinggi pada tahun 2013 ialah Provinsi Bangka Belitung (30,9\%), sedangkan prevalensi terendah terdapat di Provinsi Papua (16,8). Pravelansi hipertensi didasarkan hasil pengukuran hampir mengalami penurunan di seluruh provinsi di Indonesia, namun di Provinsi Lampung justru mengalami peningkatan dimana pada tahun 2007 adalah sebesar 24,1\% sementara pada tahun 2013 meningkat menjadi 24,7\% (Kemenkes RI, 2016).

Berdasarkan data yang tercatat di Kasie Surveilans \& Epidemiologi Dinas Kesehatan Lampung Timur menunjukkan bahwa jumlah kasus lama hipertensi mencapai 9.165 sedangkan pada laporan terakhir 2017 jumlah kasus baru hipertensi ditemukan sebanyak 2.972 kasus yang tersebar di 33 (tiga puluh tiga) Puskemas. Jumlah kasus baru terbanyak terdapat di dua Puskesmas yaitu Puskesmas Tambah Subur 375 kasus (12,6\%) dan Puskesmas Donomulyo yaitu sebanyak 374 kasus (12,5\%). Sedangkan paling sedikit ditemukan di Wilayah Kerja Puskesmas Trimulyo yaitu sebanyak 20 kasus (2,4\%) (Dinkes Lampung Timur, 2017).

Tingginya angka kejadian hipertensi dapat dipengaruhi oleh berbagai faktor baik faktor risiko yang dapat dikendalikan maupun faktor yang tidak dapat dikendalikan. Beberapa faktor risiko penyebab hipertensi yang dapat dikendalikan meliputi asupan tinggi natrium, asupan rendah kalium, kalsium, magnesium, obesitas, alkohol, perilaku merokok, dan resistensi insulin. Sementara faktor risiko yang tidak dapat dikendalikan mencakup faktor genetik, riwayat keluarga, usia, dan ras (Lemone, et al, 2016). 


\begin{abstract}
Banyaknya faktor risiko dan kondisi patologis hipertensi maka penyakit ini memerlukan penanganan/terapi yang cukup kompleks karena tekanan darah relatif tidak stabil. Penatalaksanaan hipertensi secara garis besar dikelompokkan atas terapi nonfarmakologi dan terapi farmakologi. Terapi nonfarmakologi merupakan terapi tanpa menggunakan agen obat dalam proses terapinya, sedangkan terapi farmakologis menggunakan obat atau senyawa yang dalam kerjanya dapat mempengaruhi tekanan darah pasien. Tidak dapat dipungkiri bahwa terapi farmakologi atau obat-obatan merupakan jenis racun yang dalam batas-batas tertentu merugikan dan berdampak negatif terhadap tubuh manusia bila digunakan dalam waktu yang lama. Oleh karena itu, terapi nonfarmakologi lebih diutamakan karena diyakini lebih aman dan memberikan efek positif. Diantara algoritma penanganan hipertensi melalui terapi nonfarmakologis adalah dengan memodifikasi gaya hidup termasuk diet buah tinggi serat, kalsium, magnesium serta kalium (Lewis, 2000 dalam Tarwoto, 2014).
\end{abstract}

Konsumsi buah-buahan merupakan salah satu terapi diet yang sangat penting bagi penderita hipertensi. Diantara buah yang mudah ditemukan di masyarakat dan memiliki kandungan kalium, kalsium, magnesium dan serat yang tinggi adalah buah pisang. Kadar kalium yang tinggi pada buah pisang dapat mencegah darah tinggi dan komplikasinya. Efek ini diperkuat dengan kandungan serat yang tinggi (Agoes, 2012). Efek kalium dan kalsium dapat meningkatkan vasodilatasi dengan menurunkan respons terhadap katekolamin dan angiotensin. Selain itu, magnesium juga telah terbukti menurunkan tekanan darah walaupun mekanisme kerjanya sampai saat ini masih perlu diteliti (Lemone, et al, 2016).

Penelitian yang dilakukan oleh Alini (2015) menunjukkan bahwa konsumsi buah pisang ambon ( 3 buah ukuran sedang \pm 420 gr) perhari selama 7 hari mampu menurunkan tekanan darah sistolik $14 \mathrm{mmHg}$ dan diastolic $10 \mathrm{mmHg}$. Pada hasil uji T-test dependent terbukti buah pisang ambon efektif menurunkan tekanan darah lansia pendeita hipertensi, dengan $\mathrm{p}$-value $0,000(\mathrm{p}<0,05)$. Penelitian yang dilakukan oleh Sutria dan Insani (2017) menunjukkan bahwa rata-rata tekanan darah penderita hipertensi sebelum diberikan terapi buah pisang ambon adalah 139/89 $\mathrm{mmHg}$, sedangkan setelah pemberian buah pisang ambon 3 buah ukuran sedang selama 5 hari rata-rata tekanan darah terjadi penurunan menjadi 120/77 $\mathrm{mmHg}$. Pada hasil uji wilcoxon signed ranks test didapatkan nilai signifikansi untuk tekanan darah sistolik adalah p-value 0,018 dan diastolic p-value 0,004, dengan demikian maka disimpulkan bahwa buah pisang ambon terbukti berpengaruh terhadap penurunan tekanan darah penderita hipertensi.

Pisang Ambon (Musa Paradisiaca var. Sapientum Linn) adalah jenis pisang dengan nama lain pisang cavendish. Pisang Ambon terdiri dari beragam jenis misalnya pisang Ambon lumut, pisang Ambon putih, pisang Ambon kuning, dan sebagainya. Pisang Ambon merupakan hasil perkembangbiakkan genetis dengan kultur jaringan. Pisang Ambon yang umum ditemui memiliki kulit yang halus berwarna hijau atau kuning dengan daging putih dan manis serta tidak berbiji atau berbiji sangat halus. Pisang Ambon berukuran cukup besar dengan jumlah hingga belasan pada satu sisir. Pisang Ambon banyak disediakan untuk kudapan atau makanan pencuci mulut di meja makan. Pisang Ambon diklaim lebih tahan dari penyakit yang menyebabkan pohon pisang layu. Pisang Ambon mudah ditemui di manapun, bahkan kemasan sekali makan pun tersedia di mini market (Andarita, 2014).

Pisang memiliki protein empat kali lebih banyak, karbohidrat dua kali lebih tinggi, kadar fosfor empat kali lebih tinggi, kadar vitamin A dan zat besi lima kali lebih tinggi serta kadar vitamin dan mineral lainnya dua kali lebih banyak dibanding buah apel. Selain itu, pisang juga mampu memperbaiki keadaan fisik, pikiran, serta emosi seseorang. Pisang mengandung zat besi yang cukup tinggi sehingga dapat memicu tubuh memproduksi hemoglobin lebih tinggi sehingga mencegah anemia. Pada pisang kandungan potasiumnya tinggi sehingga sangat cocok bagi orang dengan tekanan darah tinggi yang harus melakukan diet rendah garam namun tetap membutuhkan potassium (Afrianti, 2010).

Pisang ambon memiliki kandungan kalium yang tinggi. Kandungan kalium pada pisang ambon dapat membantu mengatur keseimbangan cairan dan elektrolit sehingga tekanan darah terkendali. Kandungan pisang ambon mampu mengikat lemak sehingga dapat mencegah terbentuknya plak penyebab hipertensi (Andarita, 2014). Pada pisang kandungan potasiumnya tinggi sehingga sangat cocok bagi orang dengan tekanan darah tinggi yang harus melakukan diet rendah garam namun tetap membutuhkan potassium (Afrianti, 2010).

Pisang ambon dapat menurunkan tekanan darah karena pada buah pisang ambon banyak mengandung tinggi kalium dan rendah natrium. Kalium membantu menjaga tekanan osmotik diruang intrasel sedangkan natrium menjaga tekanan osmotik dalam ruang ekstrasel sehingga kadar kalium yang tinggi dapat meningkatkan 
ekskresi natrium dalam urin (natriuresis), sehingga dapat menurunkan volume darah dan tekanan darah, namun sebaliknya penurunan kalium dalam ruang intrasel menyebabkan cairan dalam ruang intrasel cenderung tertarik keruangan ekstrasel dan retensi natrium dikarenakan respon dari tubuh agar osmolalitas pada kedua kompartemen berada pada titik ekuilibrium namun hal tersebut dapat meningkatkan tekanan darah. Selain itu pisang ambon juga memiliki aktivitas Angiotensin Converting Enzim Inhibitor (ACE-I) di dalam tubuh. Sesuai dengan namanya, zat ini menghambat kerja enzim angiotensin pada proses peningkatan tekanan darah sehingga baik untuk penderita hipertensi (Winarno,2009, dalam Sutria \& Insayni, 2015).

Schmidt (2012, dalam Tangkilisan, 2013), mengungkapkan bahwa pisang adalah buah yang mengandung kalium tinggi. Satu buah pisang berukuran sedang dapat mengandung sekitar $422 \mathrm{mg}$ kalium, atau hampir 10 $\%$ dari kebutuhan harian kalium untuk dewasa. Schmidt menerangkan bahwa kalium dapat menjaga kesehatan kardiovaskuler dengan cara mengontrol aktivitas elektrik jantung dan menurunkan tekanan darah, khususnya bagi yang memiliki resiko atau sedang mengalami peningkatan tekanan darah.

Kalium seperti yang terdapat pada buah pisang merupakan ion bermuatan positif, akan tetapi berbeda dengan natrium, kalium terutama terdapat di dalam sel. Kalium diabsorbsi dengan mudah dalam usus halus. Sebanyak 80-90\% kalium yang dimakan diekskresi melalui urin, selebihnya dikeluarkan melalui feses dan sedikit melalui keringat dan cairan lambung. Taraf kalium normal darah dipelihara oleh ginjal melalui kemampuannya menyaring, mengbasorpsi kembali dan mengeluarkan kalium di bawah pengaruh aldosteron. Kalium dikeluarkan dalam bentuk ion dengan menggantikan ion natrium melalui mekanisme pertukaran di dalam tubula ginjal. Bersama dengan natrium, kalium memegang peranan dalam pemeliharaan keseimbangan cairan dan elektrolit serta keseimbangan asam basa. Bersama kalsium, kalium berperan dalam transmisi saraf dan relaksasi otot. Di dalam sel, kalium berfungsi sebagai akatalisator dalam banyak reaksi biologik, terutama dalam pertumbuhan sel. Taraf kalium dalam otot berhubungan dengan massa otot dan simpanan glikogen. Tekanan darah normal memerlukan perbandingan antara natrium dan kalium yang sesuai di dalam tubuh. Perbandingan natrium dan kalium di dalam cairan intraselular adalah 1:10, sedangkan di dalam cairan ekstraselular 28:1. Kekurangan kalium menyebabkan lemah, lesu, kehilangan nafsu makan, kelumpuhan, mengigau, dan konstipasi. Jantung akan berdebar detaknya, dan menurunkan kemampuannya untuk memompa darah (Almatsier, 2010).

\section{Metode Penelitian}

Jenis penelitian kuantitatif, menggunakan desain pre experiment designs (pra esksperimen) rancangan one group pretest posttest. Populasi dalam penelitian ini adalah pasien baru penderita hipertensi di Wilayah kerja Puskesmas Tambah Subur Kec. Way Bungur Lampung Timur tahun 2017 yaitu sebanyak 375 orang. Sampel yang digunakan sebanyak 25 orang dengan teknik teknik purposive sampling. Prosedur pengumpulan data penelitian dilakukan melalui beberapa tahapan.

Sebelum perlakuan (pemberian buah pisang ambon) dilakukan pengukuran pertama tekanan darah responden dalam bentuk tekanan sistolik/diastolik. Hasil pengukuran pertama adalah data pre -test. Kemudian responden diberikan terapi buah pisang ambon (Musa Paradisiaca var. Sapientum Linn). Buah pisang ambon disiapkan oleh peneliti dan diberikan kepada responden. Selanjutnya responden diminta untuk mengkonsumsi 3 kali sehari (pagi, siang dan sore hari) dalam jangka waktu 1 minggu (7 hari). Setelah diberikan terapi buah pisang ambon (Musa Paradisiaca var. Sapientum Linn) selama 1 minggu, peneliti kemudian melakukan pengukuran kembali (post-test) untuk memperoleh data tentang tekanan sistolik/diastolik.

Teknik analisis menggunakan uji statistik parametrik uji $\mathrm{T}$ berpasangan (Paired T Test). Analisis ini dilakukan dengan menggunakan program komputer, keputusan uji statistik menggunakan taraf signifikan $p<0,05$. 


\section{Hasil Penelitian}

\section{Analisis Univariat}

Rata-rata Tekanan Darah Penderita Hipertensi Sebelum Perlakuan (Pre-test)

\begin{tabular}{|c|c|c|c|c|}
\hline Variabel & Mean & SD & Min-Max & CI; 95\% \\
& & & & \\
\hline Tekanan darah penderita hipertensi & $149,00 /$ & $5,132 /$ & $140-158 /$ & $146,88-151,12 /$ \\
sebelum perlakuan (pre-test) & 94,52 & 5,697 & $90-99$ & $93,50-95,54$ \\
\hline
\end{tabular}

Berdasarkan tabel di atas, dapat dijelaskan bahwa sebelum (pre-test) intervensi pemberian buah pisang ambon (Musa Paradisiaca Var. Sepientum Linn) rata-rata tekanan darah responden adalah 149,00/94,52 $\mathrm{mmHg}$ dengan standar deviasi 5,132/2,468. Tekanan darah minimum sistolik adalah $140 \mathrm{mmHg}$, maksimum $158 \mathrm{mmHg}$ dan tekanan diastolik minimum $90 \mathrm{mmHg}$, maksimum $99 \mathrm{mmHg}$. Pada confidence interval $95 \%$ diyakini bahwa rata-rata tekanan darah sistolik penderita hipertensi sebelum pemberian buah pisang ambon (Musa Paradisiaca Var. Sepientum Linn) adalah antara 1,46,88-151,12 $\mathrm{mmHg}$ dan tekanan darah diastolik antara 93,50-95,54 $\mathrm{mmHg}$.

Rata-rata Tekanan Darah Penderita Hipertensi Sesudah (Post-test) Pemberian Buah Pisang Ambon (Musa Paradisiaca Var. Sepientum Linn)

\begin{tabular}{|c|c|c|c|c|}
\hline Variabel & Mean & SD & Min-Max & CI; 95\% \\
\hline Tekanan darah penderita hipertensi & $140,04 /$ & $5,697 /$ & $130-149 /$ & $137,69-142,39 /$ \\
sesudah perlakuan (post-test) & 89,88 & 5,199 & $80-98$ & $87,73-92,03$ \\
\hline
\end{tabular}

Berdasarkan tabel di atas, dapat dijelaskan bahwa sesudah perlakuan (post-test) rata-rata tekanan darah responden adalah 140,04/89,88 $\mathrm{mmHg}$ dengan standar deviasi 5,697/5,199. Tekanan darah minimum sistolik adalah $130 \mathrm{mmHg}$, maksimum $149 \mathrm{mmHg}$ dan tekanan diastolik minimum $80 \mathrm{mmHg}$, maksimum $98 \mathrm{mmHg}$. Pada confidence interval $95 \%$ diyakini bahwa rata-rata tekanan darah sistolik penderita hipertensi setelah pemberian buah pisang ambon (Musa Paradisiaca Var. Sepientum Linn) adalah antara 137,69-142,39 mmHg dan tekanan darah diastolik antara 87,73-92,03 $\mathrm{mmHg}$.

\section{Analisis Bivariat}

Pengaruh Buah Pisang Ambon (Musa Paradisiaca Var. Sepientum Linn) terhadap Penurunan Tekanan Darah Ppda Penderita Hipertensi di Wilayah Kerja Puskesmas Tambah Subur

\begin{tabular}{|c|c|c|c|c|c|c|c|}
\hline \multirow{2}{*}{\multicolumn{2}{|c|}{ Variabel }} & \multirow{3}{*}{$\begin{array}{l}\text { Mean } \\
149,00 \\
140,04 \\
\end{array}$} & \multirow{3}{*}{$\begin{array}{c}M D \\
8,960\end{array}$} & \multirow{3}{*}{$\begin{array}{c}\boldsymbol{S D} \\
3,422\end{array}$} & \multicolumn{2}{|c|}{ CI;95\% } & \multirow{3}{*}{$\begin{array}{c}\text { p-value } \\
0,000\end{array}$} \\
\hline & & & & & \multirow{2}{*}{$\begin{array}{c}\text { Lower } \\
7,548\end{array}$} & \multirow{2}{*}{$\begin{array}{l}\text { Upper } \\
10,372\end{array}$} & \\
\hline $\begin{array}{c}\text { Tekanan darah } \\
\text { sistolik }\end{array}$ & $\begin{array}{l}\text { Pretest } \\
\text { Posttest }\end{array}$ & & & & & & \\
\hline $\begin{array}{c}\text { Tekanan darah } \\
\text { diastolik }\end{array}$ & $\begin{array}{l}\text { Pretest } \\
\text { Posttest }\end{array}$ & $\begin{array}{l}94,52 \\
89,88\end{array}$ & 4,640 & 5,090 & 2,539 & 6,741 & 0,000 \\
\hline
\end{tabular}

Berdasarkan tabel di atas dapat diketahui bahwa pada hasil analisis dengan menggunakan paired sample ttest diperoleh selisih rata-rata tekanan darah sistolik antara sebelum dan sesudah perlakuan adalah 8,960 mmHg dengan standar deviasi 3,422 $\mathrm{mmHg}$ dan selisih rata-rata tekanan darah diastolik adalah sebesar 4,640 dengan standar deviasi 5,090 $\mathrm{mmHg}$. Pada hasil uji statistik didapatkan nilai signifikansi tekanan darah sistolik dan diastolik sebesar $p$-value $0,000<\alpha 0,05$ maka dapat disimpulkan bahwa terdapat perbedaan ratarata tekanan darah penderita hipertensi sebelum dan sesudah perlakuan, artinya secara statistik terbukti ada pengaruh buah pisang ambon (Musa Paradisiaca Var. Sepientum Linn) terhadap penurunan tekanan darah pada penderita hipertensi, dimana tekanan darah sesudah diberi buah pisang ambon lebih rendah secara bermakna dibandingkan sebelum pemberian buah pisang ambon. 


\section{Pembahasan}

\section{Rata-rata Tekanan Darah Penderita Hipertensi Sebelum Perlakuan (Pre-test)}

Berdasarkan hasil pengolahan data dapat diketahui bahwa sebelum (pre-test) intervensi pemberian buah pisang ambon (Musa Paradisiaca Var. Sepientum Linn) rata-rata tekanan darah responden adalah $149,00 / 94,52 \mathrm{mmHg}$ dengan standar deviasi 5,132/2,468. Tekanan darah minimum sistolik adalah 140 $\mathrm{mmHg}$, maksimum $158 \mathrm{mmHg}$ dan tekanan diastolik minimum $90 \mathrm{mmHg}$, maksimum $99 \mathrm{mmHg}$. Pada confidence interval $95 \%$ diyakini bahwa rata-rata tekanan darah sistolik penderita hipertensi sebelum pemberian buah pisang ambon (Musa Paradisiaca Var. Sepientum Linn) adalah antara 1,46,88-151,12 mmHg dan tekanan darah diastolik antara 93,50-95,54 $\mathrm{mmHg}$.

Hipertensi adalah suatu keadaan dimana terjadi peningkatan tekanan darah secara abnormal dan terus menerus pada beberapa kali pemeriksaan tekanan darah yang disebabkan suatu atau beberapa faktor risiko yang berjalan sebagaimana mestinya dalam mempertahankan tekanan darah secara normal. Hipertensi dapat didefinisikan sebagai tekanan darah tinggi persisten dimana tekanan sistoliknya diatas $140 \mathrm{mmHg}$ dan tekanan diastolic di atas $90 \mathrm{mmHg}$ (Wijaya \& Putri, 2013). Penyebab hipertensi sendiri sangat beragam diantaranya stress, kegemukan, merokok, hipernatriumia, retensi air dan garam yang tidak normal, sensitifitas terhadap angiotensin, hiperkolesteroemia, penyakit kelenjar adrenal, penyakit ginjal, toxemia gravidarum, peningkatan tekanan intra cranial, yang disebabkan tumor otak, pengaruh obat tertentu misal obat kontrasepsi, asupan garam yang tinggi, kurang olahraga, genetic, aterosklrerosis, kelainan ginjal, tetapi sebagian tidak diketahui penyebabnya (Sharif, 2012).

Hasil penelitian ini sejalan dengan penelitian yang dilakukan Alini (2015) di Panti Sosial Tresna Wherda Khusnul Khotimah Pekanbarupada tanggal 8-14 Juni 2015 terhadap 22 orang penderita hipertensi menujukkan bahwa sebelum mengkonsumsi 3 buah pisang ambon (420 gr) perhari selama 7 hari rata-rata tekanan darah sistolik dan diastolik lansia penderita hipertensi adalah $167 \pm 9,69 \mathrm{mmHg}$ dan $92 \pm 7,72 \mathrm{mmHg}$.

Berdasarkan uraian di atas dapat dijelaskan bahwa rata-rata tekanan darah penderita hipertensi pada hasil penelitian ini yaitu 149,00/94,52 $\mathrm{mmHg}$ atau masuk dalam kategori hipertensi derajat I. Tekanan darah tinggi apabila tidak diobati dan ditanggulangi maka dalam jangka panjang akan menyebabkan kerusakan arteri dan organ yang mendapat suplai darah arteri tersebut seperti jantung, ginjal, dan otak sehingga memicu terjadinya stroke. Oleh karena itu perlu adanya penatalaksanaan yang tepat, salah satunya menggunakan pengobatan non farmakologi yaitu dengan pemberian buah yang mengandung tinggi kalium seperti buah pisang ambon.

\section{Rata-rata Tekanan Darah Penderita Hipertensi Sesudah Pemberian Buah Pisang Ambon (Musa Paradisiaca Var. Sepientum Linn) (Post-test)}

Berdasarkan hasil pengolahan data diketahui bahwa sesudah perlakuan (post-test) rata-rata tekanan darah responden adalah 140,04/89,88 $\mathrm{mmHg}$ dengan standar deviasi 5,697/5,199. Tekanan darah minimum sistolik adalah $130 \mathrm{mmHg}$, maksimum $149 \mathrm{mmHg}$ dan tekanan diastolik minimum $80 \mathrm{mmHg}$, maksimum $98 \mathrm{mmHg}$. Pada confidence interval 95\% diyakini bahwa rata-rata tekanan darah sistolik penderita hipertensi setelah pemberian buah pisang ambon (Musa Paradisiaca Var. Sepientum Linn) adalah antara 137,69-142,39 $\mathrm{mmHg}$ dan tekanan darah diastolik antara $87,73-92,03 \mathrm{mmHg}$.

Konsumsi buah-buahan merupakan salah satu terapi diet yang sangat penting bagi penderita hipertensi. Diantara buah yang mudah ditemukan di masyarakat dan memiliki kandungan kalium, kalsium, magnesium dan serat yang tinggi adalah buah pisang. Kadar kalium yang tinggi pada buah pisang dapat mencegah darah tinggi dan komplikasinya. Efek ini diperkuat dengan kandungan serat yang tinggi (Agoes, 2012). Efek kalium dan kalsium dapat meningkatkan vasodilatasi dengan menurunkan respons terhadap katekolamin dan angiotensin. Selain itu, magnesium juga telah terbukti menurunkan tekanan darah walaupun mekanisme kerjanya sampai saat ini masih perlu diteliti (Lemone, et al, 2016).

Hasil penelitian ini sejalan dengan penelitian yang dilakukan oleh Bahtiar (2016) dengan jumlah sampel pada 22 orang penderita hipertensi menunjukkan bahwa rata-rata tekanan darah sistolik penderita hipertensi sebelum pemberian buah pisang ambon adalah $140 \pm 4,4 \mathrm{mmHg}$ dan diastolik $85,83 \mathrm{mmHg}$. Selisih rata-rata 
posttest pada kelompok intervensi untuk tekanan darah sistolik adalah 18,33 $\pm 15,27 \mathrm{mmHg}$ dan diastolic $12,62 \mathrm{mmhg}$.

Berdasarkan uraian hasil penelitian di atas dapat dijelaskan bahwa setelah dilakukan perlakuan berupa pemberian buah pisang ambon sebanyak 3 buah 3 kali sehari selama 1 minggu, maka didapatkan rata-rata tekanan darah penderita hipertensi lebih rendah dibandingkan dengan sebelum perlakuan. Hal ini menunjukkan bahwa kandungan gizi pada buah pisang ambon memberikan efek terhadap penurunan tekanan darah, dimana salah satu kandungan gizi yang banyak ditemukan dalam buah pisang ambon adalah kalium atau potassium yang sangat penting untuk fungsi tubuh manusia.

\section{Pengaruh Buah Pisang Ambon (Musa Paradisiaca Var. Sepientum Linn) Terhadap Penurunan Tekanan Darah pada Penderita Hipertensi}

Hasil pengujian hipotesis menggunakan uji paired sample t-test diperoleh diperoleh selisih rata-rata tekanan darah sistolik antara sebelum dan sesudah perlakuan adalah $8,960 \mathrm{mmHg}$ dengan standar deviasi 3,422 $\mathrm{mmHg}$ dan selisih rata-rata tekanan darah diastolik adalah sebesar 4,640 dengan standar deviasi 5,090 $\mathrm{mmHg}$. Pada hasil uji statistik didapatkan nilai signifikansi tekanan darah sistolik dan diastolik sebesar pvalue $0,000<\alpha 0,05$ maka dapat disimpulkan bahwa terdapat perbedaan rata-rata tekanan darah penderita hipertensi sebelum dan sesudah perlakuan, artinya secara statistik terbukti ada pengaruh buah pisang ambon (Musa Paradisiaca Var. Sepientum Linn) terhadap penurunan tekanan darah pada penderita hipertensi, dimana tekanan darah sesudah diberi buah pisang ambon lebih rendah secara bermakna dibandingkan sebelum pemberian buah pisang ambon.

Hasil penelitian ini sejalan dengan teori yang menjelaskan bahwa pisang ambon memiliki kandungan kalium yang tinggi. Kandungan kalium pada pisang ambon dapat membantu mengatur keseimbangan cairan dan elektrolit sehingga tekanan darah terkendali. Kandungan pisang ambon mampu mengikat lemak sehingga dapat mencegah terbentuknya plak penyebab hipertensi (Andarita, 2014). Pada pisang kandungan potasiumnya tinggi sehingga sangat cocok bagi orang dengan tekanan darah tinggi yang harus melakukan diet rendah garam namun tetap membutuhkan potassium (Afrianti, 2010).

Hasil penelitian ini sejalan dengan penelitian yang dilakukan oleh Suwandi (2015) terhadap 12 responden dengan teknik purposive sampling dan menggunakan uji statistik wilcoxon signed rank test. Hasil penelitian sebelum mengkonsumsi pisang ambon, responden mengalami hipertensi sedang (75\%) dan setelah mengkonsumsi pisang ambon responden mengalami hipertensi ringan yaitu 6 responden $(50 \%)$. Uji wilcoxon signed rank test pada systole didapatkan $\mathrm{p}=0,002<\alpha=0,05$ pada diastole $\mathrm{p}=0,001<\alpha=0,05$ sehingga $\mathrm{H} 0$ ditolak dan Ha diterima artinya terdapat pengaruh mengkonsumsi pisang ambon terhadap penurunan tekanan darah.

Pada hasil penelitian di atas dapat dijelaskan bahwa buah pisang ambon terbukti berpengaruh terhadap penurunan tekanan darah penderita hipertensi. Tekanan darah penderita hipertensi setelah diberi perlakuan berupa pemberian buah pisang ambon lebih rendah secara bermakna dibandingkan sebelum diberikan buah pisang ambon. Hal ini dapat terjadi karena sebelum diberi perlakuan umumnya penderita hipertensi tidak teratur dalam mempertahankan asupan diet tinggi buah sehingga tekanan darah tidak dapat terkontrol secara baik. Sedangkan selama dilakukan perlakuan, penderita hipertensi secara teratur mempertahankan asupan diet buah pisang ambon yang mengandung tinggi kalium sebagaimana dijelaskan oleh Winarno, (2009 dalam Sutria \& Insayni, 2015) bahwa pada buah pisang ambon banyak mengandung tinggi kalium dan rendah natrium. Kalium membantu menjaga tekanan osmotik diruang intrasel sedangkan natrium menjaga tekanan osmotik dalam ruang ekstrasel sehingga kadar kalium yang tinggi dapat meningkatkan ekskresi natrium dalam urin (natriuresis), sehingga dapat menurunkan volume darah dan tekanan darah, namun sebaliknya penurunan kalium dalam ruang intrasel menyebabkan cairan dalam ruang intrasel cenderung tertarik keruangan ekstrasel dan retensi natrium dikarenakan respon dari tubuh agar osmolalitas pada kedua kompartemen berada pada titik ekuilibrium namun hal tersebut dapat meningkatkan tekanan darah. Selain itu pisang ambon juga memiliki aktivitas Angiotensin Converting Enzim Inhibitor (ACE-I) di dalam tubuh. Sesuai dengan namanya, zat ini menghambat kerja enzim angiotensin pada proses peningkatan tekanan darah sehingga baik untuk penderita hipertensi.

Schmidt (2012, dalam Tangkilisan, 2013) juga menjelaskan bahwa kalium dapat menjaga kesehatan kardiovaskuler dengan cara mengontrol aktivitas elektrik jantung dan menurunkan tekanan darah, khususnya 
bagi yang memiliki resiko atau sedang mengalami peningkatan tekanan darah. Sementara itu, Almatsier (2010) mengungkapkan bahwa kalium seperti yang terdapat pada buah pisang merupakan ion bermuatan positif, akan tetapi berbeda dengan natrium, kalium terutama terdapat di dalam sel. Kalium diabsorbsi dengan mudah dalam usus halus. Sebanyak $80-90 \%$ kalium yang dimakan diekskresi melalui urin, selebihnya dikeluarkan melalui feses dan sedikit melalui keringat dan cairan lambung. Taraf kalium normal darah dipelihara oleh ginjal melalui kemampuannya menyaring, mengbasorpsi kembali dan mengeluarkan kalium di bawah pengaruh aldosteron.

Kalium dikeluarkan dalam bentuk ion dengan menggantikan ion natrium melalui mekanisme pertukaran di dalam tubula ginjal. Bersama dengan natrium, kalium memegang peranan dalam pemeliharaan keseimbangan cairan dan elektrolit serta keseimbangan asam basa. Bersama kalsium, kalium berperan dalam transmisi saraf dan relaksasi otot. Di dalam sel, kalium berfungsi sebagai akatalisator dalam banyak reaksi biologik, terutama dalam pertumbuhan sel. Taraf kalium dalam otot berhubungan dengan massa otot dan simpanan glikogen. Tekanan darah normal memerlukan perbandingan antara natrium dan kalium yang sesuai di dalam tubuh. Perbandingan natrium dan kalium di dalam cairan intraselular adalah 1:10, sedangkan di dalam cairan ekstraselular 28:1. Kekurangan kalium menyebabkan lemah, lesu, kehilangan nafsu makan, kelumpuhan, mengigau, dan konstipasi. Jantung akan berdebar detaknya, dan menurunkan kemampuannya untuk memompa darah.

\section{Kesimpulan}

Berdasarkan hasil penelitian dan uraian pada bab sebelumnya maka dapat diambil kesimpulan bahwa distribusi karakteristik penderita hipertensi sebagian besar berusia antara 40 sampai dengan $>50$ tahun $(44,0 \%)$, jenis kelamin laki-laki $(56,0 \%)$, pendidikan SMA $(60,0 \%)$, dan pekerjaan wiraswasta $(52,0 \%)$. Rata-rata tekanan darah penderita hipertensi sebelum (pre-test) pemberian buah pisang ambon (Musa Paradisiaca Var. Sepientum Linn) adalah 149,00/94,52 mmHg dengan standar deviasi 5,132/2,468. Rata-rata tekanan darah penderita hipertensi setelah (posttest) pemberian buah pisang ambon (Musa Paradisiaca Var. Sepientum Linn) adalah 140,04/89,88 mmHg dengan standar deviasi 5,697/5,199. Rata-rata tekanan darah penderita hipertensi setelah diberi perlakuan lebih rendah secara bermakna dibandingkan sebelum diberi perlakuan.

\section{Referensi}

Agoes, Azwar (2012). Tanaman Obat Indoensia. Buku 1. Jakarta: Salemba Medika.

Alini. (2015). Pengaruh Konsumsi Pisang Ambon Terhadap Penurunan Tekanan Darah Pada Klien Lansia dengan Hipertensi Sedang Di Panti Sosial Tresna Werdha Khusnul Khotimah Pekanbaru Tahun 2015. Jurnal Ners, 6(2), 1-10.

Almatsier, Sunita. (2010). Prinsip-dasar ilmu gizi. (6th ed). Jakarta: Gramedia Pustaka Utama.

Amran Y dkk, (2010). Pengaruh Tambahan Asupan Kalium Dari Diet Terhadap Penurunan Hipertensi Sistolik dan Diatolik Tingkat Sedang Pada Lanjut Usia. Artikel Penelitian: Universitas Islam Negeri Syarif Hasanuddin Jakarta.

Andarita, Ony, (2014). Dasyatnya 50 Buah dan Sayuran. Jakarta: Pustaka Agung Harapan.

Arikunto, Suharsimi, (2012). Prosedur Penelitian Suatu Pendekatan Praktek. Jakarta: Rineka Cipta.

Bahtiar, S. (2016). Tekanan Darah Penderita Hipertensi Di Dusun Jitengan Balecatur Gamping Sleman Yogyakarta. Journal Universitas Aisyiyah. Yogyakarta.

Black M.J. \& Hawks. H.J. (2014) Keperawatan Medikal Bedah Manajemen Klinik Untuk hasil yang diharapkan. Edisi 8 Buku 2, Singapure: Elsevier.

Dinkes Kota Metro, Laporan Penyakit Tidak Menular Kota Metro 2017

Haryono, Rudi \& Setianingsih, Sulis (2013). Awas Musuh-musuh anda setelah usia 40 tahun. Yogyakarta: Gosyen Publising 
Hidayat, Alimul, Aziz (2007). Metode Penelitian Kebidanan Teknik Analisa Data. Jakarta: Salemba Medika.

Lemone, P., Bukes. K.M., Bauldoff. G. (2016) Buku Ajar Keperawatan Medikal Bedah. Vol 3 Edisi 5. Jakarta: Penerbit Buku Kedokteran. EGC.

Muttaqin, A. (2014) Buku Ajar Asuhan Keperawatan Klien dengan Gangguan Sistem Kardiovaskular dan Hematologi. Jakarta: Salemba Medika

Notoatmodjo, Sukidjo (2011) Kesehatan Masyarakat Ilmu dan Seni. Jakarta: Rineka Cipta

Notoatmodjo, Sukidjo (2012). Metodologi Penelitian, Jakarta: Rineka Cipta

Rahimsyah, AR (2016) Herbal dan Pijat Refleksi untuk Penyembuhan dan Fitalitas. Surabaya: Media Pustaka

Riskesdas (2013) Riset Kesehatan Dasar. Jakarta: Badan Penelitian dan Pengembangan Kesehatan Kementrian Kesehatan Indonesia.

Smeltzer, S.C (2018). Keperawatan Medikal Bedah Brunner \& Suddarth, Edisi 12. Jakarta: EGC

Sugiyono, (2010). Statistik Non Parametris Untuk Penelitian, Jakarta : Alfa Beta

Sutria, E., \& Insani, A. (2017). Pengaruh Komsumsi Pisang Ambon Terhadap Penurunan Tekanan Darah Pra Lansia Hipertensi. Journal of Islamic Nursing, 1(1), 33-40.

Suwandi, M. M. (2015). Pengaruh Mengkonsumsi Pisang Ambon Terhadap Penurunan Tekanan Darah Pada Lansia Penderita Hipertensi Di Panti Werdha Mojopahit Kabupaten Mojokerto. Skripsi Keperawatan. Poltekes Majapahit. Mojokerto

Triyanto, E. (2014). Pelayanan Keperawatan bagi Penderita Hipertensi Secara Terpadu. Yogyakarta: Graha Ilmu.

WHO, (2017). Raised blood pressure, Diambil pada 27 Maret 2018 dari http://www.who.int

Wijaya, Saferi, Andra \& Putri, Mariza, Yessie (2013). KMB 1 Keperawatan Medikal Bedah, Nuha Yogyakarta : Medika.. 